\title{
Effects of Temperature on the Composition and Xanthine Oxidase Inhibitory Activities of Caffeic Acid Roasting Products
}

\author{
Toshiya Masuda, Yuya Fukuyama, Sayaka Doi, Akiko Masuda, \\ Shinichiro Kurosawa, Shigeyoshi Fujii
}

\begin{tabular}{|c|l|}
\hline Citation & Journal of Agricultural and Food Chemistry, 67(32); 8977-8985 \\
\hline Issue Date & 2019-07-23 \\
\hline Type & Journal Article \\
\hline Textversion & author \\
\hline Rights & $\begin{array}{l}\text { This document is the Accepted Manuscript version of a Published Work that appeared } \\
\text { in final form in Journal of Agricultural and Food Chemistry, copyright } @ \text { American } \\
\text { Chemical Society after peer review and technical editing by the publisher. } \\
\text { To access the final edited and published work see } \\
\text { https://doi.org/10.1021/acs.jafc.9b03633. }\end{array}$ \\
\hline $\begin{array}{c}\text { Supporting } \\
\text { Information }\end{array}$ & $\begin{array}{l}\text { The Supporting Information is available free of charge on the ACS Publications } \\
\text { website at https://doi.org/10.1021/acs.jafc.9b03633 }\end{array}$ \\
\hline DOI & 10.1021/acs.jafc.9b03633 \\
\hline
\end{tabular}

Self-Archiving by Author(s)

Placed on: Osaka City University

Toshiya Masuda, Yuya Fukuyama, Sayaka Doi, Akiko Masuda, Shinichiro Kurosawa, Shigeyoshi Fujii. (2019). Effects of Temperature on the Composition and Xanthine Oxidase Inhibitory Activities of Caffeic Acid Roasting Products. Journal of Agricultural and Food Chemistry. 67. pp.8977-8985 DOI:10.1021/acs.jafc.9b03633 


\title{
1 Effects of Temperature on the Composition and Xanthine Oxidase Inhibitory Activities of Caffeic Acid Roasting Products
}

\author{
${ }_{3}$ Toshiya Masuda, ${ }^{*}{ }^{\dagger}$ Y Yuya Fukuyama, ${ }^{\dagger}$ Sayaka Doi, ${ }^{\dagger}$ Akiko Masuda, ${ }^{\dagger}$ Shinichiro Kurosawa, ${ }^{\S}$ \\ 4 and Shigeyoshi Fujii ${ }^{\S}$ \\ $5{ }^{\dagger}$ Graduate School of Human Life Science, Osaka City University, Sumiyoshi, Osaka 558-8585, Japan \\ $6{ }^{*}$ Faculty of Human Life Science, Shikoku University, Tokushima 771-1192, Japan \\ $7{ }^{\S}$ Technical Research and Development Institute, Ajinomoto AGF, Inc., Sanken Building, 3-25-1, Hyakunin-cho Shinjuku-ku, Tokyo \\ 8 169-0073, Japan
}

9 S Supporting Information

10 ABSTRACT: The high-temperature treatment of caffeic acid by a model reaction for the processing of foods by roasting 11 enhanced its xanthine oxidase (XO) inhibitory activity. The thermal reaction products included various oligomeric compounds, 12 whose structures were determined as being produced via the intermediate 4-vinylcatechol. Measurements of their XO inhibitory 13 activities were also carried out. Among the identified oligomers, the coupling products of caffeic acid and vinylcatechol, which 14 were mainly produced at $140-170{ }^{\circ} \mathrm{C}$, presented stronger $\mathrm{XO}$ inhibitory activities than the other types of oligomers produced. 15 Further reacted compounds, which were mainly formed at $200{ }^{\circ} \mathrm{C}$ by the addition or elimination of catechol unit in the 16 oligomers, displayed weaker activities. These results indicated that thermal enhancement of the XO inhibitory activity of caffeic 17 acid can be explained by the differences in the $\mathrm{XO}$ inhibitory activities of the various constituents of the thermal reaction 18 products. Caffeic acid and its derivatives are polyphenols found widely distributed in foods. Moreover, XO inhibition is closely 19 related to the prevention of the life-style-related disease gout. The results suggest that a simple roasting process $\left(170{ }^{\circ} \mathrm{C}\right)$ can 20 lend useful human-health-related functionalities to caffeic acid containing foods such as coffee.

21 KEYWORDS: thermal reaction, caffeic acid, xanthine oxidase inhibition, roasting temperature, structure identification

\section{INTRODUCTION}

23 Roasting is a high-temperature cooking method (130-230 $24{ }^{\circ} \mathrm{C}$ ), ${ }^{1}$ that is applied to grains, vegetables, meats, and fish in 25 both industrial food processing and home cooking. ${ }^{2}$ Roasting 26 can cause various thermal reactions of the food's chemical 27 constituents, thereby developing the flavors and color. ${ }^{1,3}$ ${ }_{28}$ Caffeic acid is a polyphenol that is widely distributed in 29 plant foods in its free or bound forms. Coffee beans contain 30 free caffeic acid as well as a large amount of chlorogenic acid, a 31 major caffeic acid derivative. ${ }^{4,5}$ The roasting of coffee beans at 32 approximately $200{ }^{\circ} \mathrm{C}$ is indispensable for making coffee 33 beverages. During the roasting process, caffeic acid derivatives 34 are degraded into various compounds, including disassembled 35 caffeic acid. 6,7 The degraded products react with each other to 36 afford more complex substances, ${ }^{8}$ which affect the flavor and 37 taste as well as the human health functions of roasted coffee 38 beverages. ' To date, many thermal reaction products have 39 been identified in roasted coffee beans, including volatile 40 flavoring compounds, ${ }^{10}$ Maillard reaction products, ${ }^{11}$ bitter41 tasting chlorogenic lactones, ${ }^{12}$ and phenylindane derivatives. ${ }^{13}$ 42 Recently, several epidemiological studies by Choi et al. ${ }^{14}$ and 43 other groups ${ }^{15}$ have reported that coffee drinking reduces the 44 risk of gout. Additionally, we recently discovered that roasted 45 coffee bean extract exhibits xanthine oxidase (XO) inhibitory 46 activity. ${ }^{16}$ We also reported the presence of several inhibitors 47 in roasted coffee beans. ${ }^{17} \mathrm{XO}$ is a key enzyme in the catabolism 48 of purine to uric acid, the substance that causes gout when it 49 overaccumulates in plasma. ${ }^{18}$ Stadler et al. ${ }^{19}$ were the first to report that phenylindanes were produced from the thermal 50 treatment of caffeic acid via a vinylcatechol intermediate. 51 These compounds were observed in roasted coffee beans and 52 play a role in the bitter taste of coffee. ${ }^{13}$ We also reported 53 moderate XO inhibitory activities for some phenylindanes. ${ }^{20} 54$

In this investigation, we found maximum $\mathrm{XO}$ inhibitory 55 activity for the caffeic acid products of thermal treatment at 56 around $170{ }^{\circ} \mathrm{C}$. These conditions were used as a model 57 reaction of the roasting process, and notably, differences in the 58 thermal reaction products were found between 110 and 29059 ${ }^{\circ} \mathrm{C}$. Herein, we report the structures of the constituent 60 compounds of the thermal reaction products $\left(140-200{ }^{\circ} \mathrm{C}\right) 61$ and their $\mathrm{XO}$ inhibitory activities.

\section{MATERIALS AND METHODS}

63

Chemicals and Instruments. Caffeic acid was obtained from 64 Kanto Chemicals (Tokyo, Japan). Xanthine oxidase (XO) was 65 purchased from Wako Pure Chemicals (Osaka, Japan). Allopurinol 66 was obtained from Sigma-Aldrich (St. Louis, MO). All other reagents 67 and solvents were purchased from Nacalai Tesque (Kyoto, Japan). 68 NMR spectra were obtained from a JNM-ECZ400S $(400 \mathrm{MHz}, 69$ JEOL, Tokyo, Japan) or ARX600 (600 MHz, Bruker Japan, 70 Yokohama, Japan) instrument. MS spectra were measured using a 71 JMS-T100 spectrometer (JEOL) with direct analysis at real time 72

Received: June 11, 2019

Revised: July 18, 2019

Accepted: July 23, 2019

Published: July 23, 2019 
73 (DART) or electrospray ionization (ESI) and time-of-flight (TOF) 74 measuring mode under the following conditions: DART (positive 75 mode): orifice $1,10 \mathrm{~V}$; orifice $2,5 \mathrm{~V}$; ring lens, $10 \mathrm{~V}$; helium gas 76 pressure, $0.5 \mathrm{MPa}$; flow rate, $10 \mathrm{~L} / \mathrm{min}$; ion resource temperature, 350 $77^{\circ} \mathrm{C}$; grid voltage, $400 \mathrm{~V}$. ESI (positive mode): orifice $1,85 \mathrm{~V}$ and 80 $78{ }^{\circ} \mathrm{C}$; orifice $2,5 \mathrm{~V}$; ring lens, $15 \mathrm{~V}$; helium gas pressure, $0.7 \mathrm{MPa}$; 79 needle, $2000 \mathrm{~V}$; desolvating chamber temperature, $250^{\circ} \mathrm{C}$. Elemental 80 compositions of compounds were calculated using MassLynx 81 software, version 4.1 (Waters Japan, Tokyo, Japan) from high82 resolution MS (HR-MS) data. Analytical HPLC was performed using 83 a PU-4180 RHPLC quaternary gradient pump (JASCO, Tokyo, 84 Japan) equipped with an $\mathrm{MD}-4015$ photodiode array detector 85 (JASCO) and a CTO-10AS column oven (Shimadzu, Kyoto, 86 Japan). Data were analyzed using the ChromNAV software (v. 2, 87 JASCO). Preparative HPLC was performed using an LC-6AD pump 88 (Shimadzu) equipped with an SPD-6A UV detector (Shimadzu).

89 Thermal Reaction of Caffeic Acid and HPLC Analysis of the 90 Reaction Products. In a screw-capped test tube (i.d. of $8 \mathrm{~mm}$ and 91 length of $100 \mathrm{~mm}$ ) were placed $10 \mathrm{mg}$ of caffeic acid in methanol $92(200 \mu \mathrm{L})$ and $400 \mu \mathrm{L}$ of phosphate buffer $(500 \mathrm{mmol} / \mathrm{L}, \mathrm{pH} 6.0$, $93 \mathrm{Na}_{2} \mathrm{HPO}_{4}$, and $\mathrm{KH}_{2} \mathrm{PO}_{4}$ ). After removal of the solvent in vacuo, the 94 tube was heated in a metal block bath (MB-1H-UII, KPI, Itami, 95 Japan) at the appropriate temperatures $\left(110-290{ }^{\circ} \mathrm{C}\right)$ for $0.5 \mathrm{~h}$. After 96 the tube cooled, methanol $(1 \mathrm{~mL})$ was added, and the mixture was 97 centrifuged at $2000 \mathrm{rpm}$ for $5 \mathrm{~min}$ at $25{ }^{\circ} \mathrm{C}$. Subsequently, the 98 supernatant was collected, and the solvent was removed by 99 evaporation to give the thermal reaction products. A portion of the 100 reaction products was used for the XO inhibitory assay. The 101 constituents in the products were analyzed by HPLC (Cosmosil 102 5C18-AR-II column, Nacalai, Kyoto, Japan; $250 \times 4.6 \mathrm{~mm}$ i.d., $5 \mu \mathrm{m}$; 103 flow rate, $1.0 \mathrm{~mL} / \mathrm{min}$; solvent $\mathrm{A}, 1 \%$ acetic acid in $\mathrm{H}_{2} \mathrm{O}$; solvent $\mathrm{B}$, $104 \mathrm{CH}_{3} \mathrm{CN}$; linear gradient from $5 \%$ solvent $\mathrm{B}$ to $45 \%$ solvent $\mathrm{B}$ for 40 $105 \mathrm{~min}$, then from $45 \%$ solvent B to $100 \%$ solvent B for $10 \mathrm{~min}$, and then $106100 \%$ solvent B for $5 \mathrm{~min}$; and detection at 280 and $320 \mathrm{~nm}$ ).

107 Gel Permeation Chromatography (GPC) Analysis of the 108 Thermal Reaction Products. The thermal reaction products 109 (weight corresponding to $6 \mathrm{mg}$ of initial caffeic acid) were treated 110 with acetic anhydride $(0.5 \mathrm{~mL})$ and pyridine $(0.5 \mathrm{~mL})$ at $25{ }^{\circ} \mathrm{C}$ for 1 $111 \mathrm{~h}$. After removal of acetic acid and pyridine in vacuo, the residue was 112 dissolved in THF to produce an analytical solution $(0.4 \mathrm{mg} / \mathrm{mL}$, 113 corresponding to the initial caffeic acid concentration). The solution $114(15 \mu \mathrm{L})$ was injected into a GPC column (GPC KF-803, $300 \times 8 \mathrm{~mm}$ 115 i.d., Shodex, Tokyo, Japan) for analysis (solvent, HPLC-grade THF; 116 flow rate, $1.0 \mathrm{~mL} / \mathrm{min}$; temperature, $30{ }^{\circ} \mathrm{C}$; and detection at $264 \mathrm{~nm}$ ). 117 Molecular size calibration was performed under the same conditions 118 using polystyrene standards (266, 2280, 6540, and $25500 \mathrm{Da}$ 119 polystyrene; Ready Cal-Kit Poly(styrene) Low, Sigma-Aldrich, St. 120 Louis, MO).

121 Isolation of the Thermal Reaction Product Constituents 122 from the Large-Scale Thermal Reactions of Caffeic Acid at $123 \mathbf{1 4 0 - 2 0 0}{ }^{\circ} \mathrm{C}$. For thermal treatment at $140{ }^{\circ} \mathrm{C}$, caffeic acid $(10 \mathrm{~g})$ 124 was dissolved in $100 \mathrm{~mL}$ of methanol and $400 \mathrm{~mL}$ of $500 \mathrm{mmol} / \mathrm{L}$ $125 \mathrm{Na}_{2} \mathrm{HPO}_{4}-\mathrm{KH}_{2} \mathrm{PO}_{4}$ ( $\mathrm{pH}$ 6.0) and subsequently evaporated to 126 dryness. The solid residue was heated at $140{ }^{\circ} \mathrm{C}$ for $90 \mathrm{~min}$. After 127 cooling, the reaction mixture was extracted twice with $1 \mathrm{~L}$ of 128 methanol, and this procedure was repeated 10 times. The methanol 129 extracts were combined, and the solvent was removed. The resultant 130 residue was further purified to isolate the constituent compounds. A 131 portion $(84 \mathrm{~g})$ of the residue was subjected to Amberlite XAD-7 132 (Organo, Tokyo, Japan) column chromatography and eluted with 133 increasing concentrations of methanol (50 to 100\%) in water to 134 produce eight separate fractions. Fraction 3 (208 mg of $6.5 \mathrm{~g}$ ), which 135 was eluted with $60 \%$ methanol in water, was purified by preparative 136 HPLC (Cosmosil 5C18-AR-II column, $250 \times 20 \mathrm{~mm}$ i.d.; solvent, $1 \%$ 137 acetic acid in 85:15 $\mathrm{H}_{2} \mathrm{O}-\mathrm{CH}_{3} \mathrm{CN}$; flow rate, $9.6 \mathrm{~mL} / \mathrm{min}$; and 138 detection at $280 \mathrm{~nm}$ ) to yield compounds $1-4$ in $2,6,3$, and $3 \mathrm{mg}$ 139 yields, respectively. Fraction 6 (14.3 g), which was eluted with $75 \%$ 140 methanol in water from the XAD-7 column, was subjected to 141 Sephadex LH-20 (GE Healthcare, Hino, Japan) column chromatog142 raphy $(1.5 \mathrm{~L}$ column) and eluted with methanol to produce $5 \mathrm{~g}$ of residue, which was collected from 1.5 to $1.65 \mathrm{~L}$ of total elution 143 volume. A part of the residue $(656 \mathrm{mg})$ was purified by preparative 144 HPLC (Cosmosil 5C18-AR-II column, $250 \times 20 \mathrm{~mm}$ i.d.; solvent, $1 \% 145$ acetic acid in $75: 25 \mathrm{H}_{2} \mathrm{O}-\mathrm{CH}_{3} \mathrm{CN}$; flow rate, $9.6 \mathrm{~mL} / \mathrm{min}$; and 146 detection at $280 \mathrm{~nm}$ ) to produce compounds 5-8 in 5, 4, 87, and 134147 mg yields, respectively, along with $52 \mathrm{mg}$ of a mixture of compounds 9148 and 10. This mixture was separated by HPLC in recycle mode (11 149 times, under the following conditions: Cosmosil 5C18-AR-II column, 150 $250 \times 20 \mathrm{~mm}$ i.d.; solvent, $1 \%$ acetic acid in $45: 55 \mathrm{H}_{2} \mathrm{O}-\mathrm{CH}_{3} \mathrm{OH} ; 151$ flow rate, $9.6 \mathrm{~mL} / \mathrm{min}$; and detection at $280 \mathrm{~nm}$ ) to produce pure 9152 and $\mathbf{1 0}$ in $5 \mathrm{mg}$ yields.

For thermal treatment at $200{ }^{\circ} \mathrm{C}, 40 \mathrm{~mL}$ of phosphate buffer $(\mathrm{pH} 154$ $6.0,0.5 \mathrm{~mol} / \mathrm{L})$ was added to caffeic acid $(1 \mathrm{~g})$ in methanol $(20 \mathrm{~mL}) 155$ and mixed well. After removal of the solvent from the mixture in 156 vacuo, the residual solid was heated at $200{ }^{\circ} \mathrm{C}$ for $30 \mathrm{~min}$. The 157 resulting dark-colored residue was extracted twice with methanol ( $\begin{array}{ll}50 & 158\end{array}$ $\mathrm{mL}$ ) to produce $0.76 \mathrm{~g}$ of extract after evaporation. The extract was 159 fractionated by XAD-7 column chromatography eluting with 160 increasing concentrations of methanol (10 to 100\%) in water. Two 161 fractions, eluted with 50 and $75 \%$ methanol, were evaporated to 162 produce fractions I and II in 74 and $86 \mathrm{mg}$ yields, respectively. A 163 portion $(32 \mathrm{mg})$ of the residue of fraction I was purified by HPLC 164 (Cosmosil 5C18-AR-II column, $250 \times 20 \mathrm{~mm}$ i.d.; solvent, $1 \%$ acetic 165 acid in 90:10 $\mathrm{H}_{2} \mathrm{O}-\mathrm{CH}_{3} \mathrm{CN}$; flow rate, $9.6 \mathrm{~mL} / \mathrm{min}$; and detection at 166 $280 \mathrm{~nm}$ ) to give compound $\mathbf{1 1} \mathrm{in}$ a $1 \mathrm{mg}$ yield. Likewise, the residue 167 of fraction II $(37 \mathrm{mg}$ ) was separated by HPLC (Cosmosil 5C18-AR-II 168 column, $250 \times 20 \mathrm{~mm}$ i.d.; solvent, $1 \%$ acetic acid in 70:30 $\mathrm{H}_{2} \mathrm{O}-169$ $\mathrm{CH}_{3} \mathrm{CN}$; flow rate, $9.6 \mathrm{~mL} / \mathrm{min}$; and detection at $280 \mathrm{~nm}$ ) to produce 170 compounds 5-8 and 12 in $1,5,1,2$, and 2 mg yields, respectively. 171 Another reaction product $(570 \mathrm{mg})$, which was obtained from the 172 thermal treatment of caffeic acid $(1 \mathrm{~g})$ under the same conditions, was 173 fractionated by XAD-7 column chromatography using the same 174 protocol as described above. The fraction eluted with $90 \%$ methanol 175 (195 mg) was separated by HPLC (Cosmosil 5C18-AR-II column, 176 $250 \times 20 \mathrm{~mm}$ i.d.; solvent, $1 \%$ acetic acid in $45: 55 \mathrm{H}_{2} \mathrm{O}-\mathrm{CH}_{3} \mathrm{CN} ; 177$ flow rate, $9.6 \mathrm{~mL} / \mathrm{min}$; and detection at $280 \mathrm{~nm}$ ) to produce 178 compounds 13, 14, and 16-18 in 5, 4, 3, 2, and $2 \mathrm{mg}$ yields, 179 respectively. The product $(17.1 \mathrm{~g})$ of a third thermal reaction of 180 caffeic acid $(20 \mathrm{~g})$ was also fractionated into five fractions by XAD-7 181 column chromatography under the same conditions. The fraction 182 eluted with $70 \%$ methanol $(2 \mathrm{~g})$ produced four subsequent fractions 183 (4-1 to 4-4) in 523, 61, 80, and $47 \mathrm{mg}$ yields, respectively (retention 184 times: fraction 4-1, 9-24 min; fraction 4-2, $27 \mathrm{~min}$; fraction 4-3, 33185 $\mathrm{min}$; and fraction 4-4, $40 \mathrm{~min}$ ) under the following conditions: 186 Cosmosil 5C18-AR-II column, $250 \times 20 \mathrm{~mm}$ i.d.; solvent, $1 \%$ acetic 187 acid in 70:30 $\mathrm{H}_{2} \mathrm{O}-\mathrm{CH}_{3} \mathrm{CN}$; flow rate, $9.6 \mathrm{~mL} / \mathrm{min}$; and detection at 188 $280 \mathrm{~nm}$. Compound $13(15 \mathrm{mg})$ was isolated from fraction 4-1 (487 189 $\mathrm{mg}$ ) by HPLC with a retention time of $41 \mathrm{~min}$ (Cosmosil 5C18-AR-II 190 column, $250 \times 20 \mathrm{~mm}$ i.d.; solvent, $1 \%$ acetic acid in $60: 40 \mathrm{H}_{2} \mathrm{O}-191$ $\mathrm{CH}_{3} \mathrm{OH}$; flow rate, $6.7 \mathrm{~mL} / \mathrm{min}$; and detection at $\left.280 \mathrm{~nm}\right) .192$ Compound 15 (7 mg) was isolated from fraction 4-2 (20 mg) by 193 HPLC with a retention time of $37 \mathrm{~min}$ (Cosmosil 5C18-AR-II 194 column, $250 \times 20 \mathrm{~mm}$ i.d.; solvent, $1 \%$ acetic acid in $45: 55 \mathrm{H}_{2} \mathrm{O}-195$ $\mathrm{CH}_{3} \mathrm{OH}$; flow rate, $4.8 \mathrm{~mL} / \mathrm{min}$; and detection at $\left.280 \mathrm{~nm}\right) .196$ Compounds $14(10 \mathrm{mg})$ and $17(14 \mathrm{mg})$ were obtained from 197 fraction 4-3 (70 mg) by HPLC with retention times of 43 and $45 \mathrm{~min}, 198$ respectively (Cosmosil 5C18-AR-II column, $250 \times 20 \mathrm{~mm}$ i.d.; 199 solvent, $1 \%$ acetic acid in 45:55 $\mathrm{H}_{2} \mathrm{O}-\mathrm{CH}_{3} \mathrm{OH}$; flow rate, $4.8 \mathrm{~mL} / 200$ $\mathrm{min}$; and detection at $280 \mathrm{~nm})$. Finally, compound $\mathbf{1 8}(6 \mathrm{mg})$ was 201 isolated from fraction 4-4 $(33 \mathrm{mg})$ by HPLC with a retention time of 202 $50 \mathrm{~min}$ (Cosmosil 5C18-AR-II column, $250 \times 20 \mathrm{~mm}$ i.d.; solvent, $1 \% 203$ acetic acid in 45:55 $\mathrm{H}_{2} \mathrm{O}-\mathrm{CH}_{3} \mathrm{OH}$; flow rate, $4.8 \mathrm{~mL} / \mathrm{min}$; and 204 detection at $280 \mathrm{~nm}$ ).

Analytical Data for the Structures of Compounds 5, 6, and 206 11-18. Chemical structures of the isolated products, except for the 207 previously identified phenylindanes (compounds 1-4, 7, and 8), were 208 elucidated by using the NMR and MS data on their intact or 209 acetylated forms, which were derived by acetylation with acetic 210 anhydride in pyridine. The data are listed as follows, and position 211 
212 numbering of each compound is tentative, as shown in the structures 213 in Figure 3.

214 Compound 5. HR-ESIMS $(\mathrm{m} / z)[\mathrm{M}+\mathrm{Na}]^{+}$calcd for $215 \mathrm{C}_{16} \mathrm{H}_{16} \mathrm{O}_{4} \mathrm{Na} 295.0946$, found 298.0969, and $[2 \mathrm{M}+\mathrm{Na}]^{+}$calcd for $216 \mathrm{C}_{32} \mathrm{H}_{32} \mathrm{O}_{8} \mathrm{Na}$ 567.1995, found 567.2003; ${ }^{1} \mathrm{H}$ NMR $\left(\mathrm{CD}_{3} \mathrm{OD}\right) \delta 6.69$ $217\left(4 \mathrm{H}, \mathrm{s}, \mathrm{H} 3, \mathrm{H} 6, \mathrm{H}^{\prime}\right.$, and $\left.\mathrm{H}^{\prime}{ }^{\prime}\right), 3.75\left(2 \mathrm{H}, \mathrm{q}, J=7.4 \mathrm{~Hz}, \mathrm{H} 7\right.$ and $\left.\mathrm{H}^{\prime}{ }^{\prime}\right)$, 218 and $1.43\left(6 \mathrm{H}, \mathrm{d}, J=7.4 \mathrm{~Hz}, \mathrm{H} 8\right.$ and $\left.\mathrm{H}^{\prime}{ }^{\prime}\right)$.

219 Compound 6. HR-ESIMS $(\mathrm{m} / z)[\mathrm{M}+\mathrm{Na}]^{+}$calcd for $220 \mathrm{C}_{14} \mathrm{H}_{14} \mathrm{O}_{4} \mathrm{Na} 269.0790$, found 269.0817 , and $[2 \mathrm{M}+\mathrm{Na}]^{+}$calcd for $221 \mathrm{C}_{28} \mathrm{H}_{28} \mathrm{O}_{8} \mathrm{Na} 515.1682$, found 515.1690; ${ }^{1} \mathrm{H}$ NMR $\left(\mathrm{CD}_{3} \mathrm{OD}\right) \delta 6.65$ $222\left(2 \mathrm{H}, \mathrm{d}, J=1.6 \mathrm{~Hz}, \mathrm{H} 3\right.$ and $\left.\mathrm{H}^{\prime}\right), 6.70(2 \mathrm{H}, \mathrm{d}, J=8.2 \mathrm{~Hz}, \mathrm{H} 6$ and $\left.223 \mathrm{H5}^{\prime}\right), 6.57\left(2 \mathrm{H}, \mathrm{dd}, J=8.2\right.$ and $1.6 \mathrm{~Hz}, \mathrm{H} 5$ and $\left.\mathrm{H}^{\prime}\right), 3.87(1 \mathrm{H}, \mathrm{q}, J=$ $2247.2 \mathrm{~Hz}, \mathrm{H} 7)$, and $1.52(3 \mathrm{H}, \mathrm{d}, J=7.2 \mathrm{~Hz}, \mathrm{H} 8)$.

225 Compound 9. HR-DARTMS $(m / z)[\mathrm{M}+\mathrm{H}]^{+}$calcd for $\mathrm{C}_{24} \mathrm{H}_{25} \mathrm{O}_{6}$ 226 409.1651, found 409.1656. For NMR results, see Table S1 in the 227 Supporting Information.

228 Compound 10. HR-DARTMS $(\mathrm{m} / z)[\mathrm{M}+\mathrm{H}]^{+}$calcd for $229 \mathrm{C}_{24} \mathrm{H}_{25} \mathrm{O}_{6}$ 409.1651, found 409.1652. For NMR results, see Table $230 \mathrm{~S} 1$ in the Supporting Information.

231 Compound 11. DARTMS $(m / z)[\mathrm{M}+\mathrm{H}]^{+} 111 ;{ }^{1} \mathrm{H}$ NMR 232 (acetone- $\left.d_{6}\right) \delta 6.65\left(2 \mathrm{H}, \mathrm{AA}^{\prime} \mathrm{BB}^{\prime}\right.$ coupling, $\mathrm{H} 3$ and $\left.\mathrm{H} 6\right)$ and 6.79 $233\left(2 \mathrm{H}, \mathrm{AA}^{\prime} \mathrm{BB}^{\prime}\right.$ coupling, $\mathrm{H} 4$ and $\left.\mathrm{H} 5\right)$.

234 Compound 12. DARTMS $(m / z)[\mathrm{M}+\mathrm{H}]^{+} 139 ;{ }^{1} \mathrm{H}$ NMR $235\left(\mathrm{CD}_{3} \mathrm{OD}\right) \delta 6.65(1 \mathrm{H}, \mathrm{d}, J=1.9 \mathrm{~Hz}, \mathrm{H} 3), 6.69(1 \mathrm{H}, \mathrm{d}, J=8.0 \mathrm{~Hz}$, $236 \mathrm{H} 5), 6.53(1 \mathrm{H}, \mathrm{dd}, J=8.0$ and $1.9 \mathrm{~Hz}, \mathrm{H} 6), 2.52(2 \mathrm{H}, \mathrm{q}, J=7.4 \mathrm{~Hz}$, $\left.2374-\mathrm{C}_{2}-\mathrm{CH}_{3}\right), 1.20\left(3 \mathrm{H}, \mathrm{t}, J=7.4 \mathrm{~Hz}, 4-\mathrm{CH}_{2}-\mathrm{CH}_{3}\right)$.

238 Compound 13. HR-ESIMS $[\mathrm{M}+\mathrm{Na}]^{+}$calcd for $\mathrm{C}_{14} \mathrm{H}_{14} \mathrm{O}_{4} \mathrm{Na}$ 239269.0790 , found 269.0816, and $[2 \mathrm{M}+\mathrm{Na}]^{+}$calcd for $\mathrm{C}_{28} \mathrm{H}_{28} \mathrm{O}_{8} \mathrm{Na}$ 240515.1682 , found $515.1667 ;{ }^{1} \mathrm{H}$ NMR $\left(\mathrm{CDCl}_{3}\right)$ of tetraacetate $(13 \mathrm{a}) \delta$ 241 6.99-7.03 (2H, complex, H3 and H5), 7.06-7.12 (3H, complex, H6, $242 \mathrm{H}^{\prime}$, and $\left.\mathrm{H6}^{\prime}\right), 4.25(1 \mathrm{H}, \mathrm{q}, J=7.0 \mathrm{~Hz}, \mathrm{H} 7), 1.57(3 \mathrm{H}, \mathrm{d}, J=7.0 \mathrm{~Hz}$, $243 \mathrm{H} 8), 7.23\left(1 \mathrm{H}, \mathrm{dd}, J=8.6\right.$ and $\left.8.2 \mathrm{~Hz}, \mathrm{H}^{\prime}\right), 2.18\left(3 \mathrm{H}, \mathrm{s}, 1-, 2-, 2^{\prime}\right.$-, or $\left.2443^{\prime}-\underline{\mathrm{C}}_{3} \mathrm{CO}\right), 2.25\left(3 \mathrm{H}, \mathrm{s}, 1-, 2^{-}, 2^{\prime}\right.$-, or $\left.3^{\prime}-\mathrm{C}_{\underline{3}} \mathrm{CO}\right), 2.26(6 \mathrm{H}, \mathrm{s}, 1-$, 2-, $2452^{\prime}$-, or $\left.3^{\prime}-\mathrm{CH}_{3} \mathrm{CO}\right)$.

246 Compound 14. HR-DARTMS $[\mathrm{M}+\mathrm{H}]^{+}$calcd for $\mathrm{C}_{10} \mathrm{H}_{13} \mathrm{O}_{2}$ 247 165.0916, found 165.0914; ${ }^{1} \mathrm{H}$ NMR $\left(\mathrm{CDCl}_{3}\right)$ of diacetate of 14, $\delta$ $2483.17(1 \mathrm{H}$, sext, $J=7.6 \mathrm{~Hz}, \mathrm{H1}), 1.64(1 \mathrm{H}, \mathrm{dq}, J=12.4$ and $7.6 \mathrm{~Hz}$, $249 \mathrm{H} 2 \mathrm{a}), 2.29(1 \mathrm{H}, \mathrm{ddt}, J=12.4,7.6$, and $4.0 \mathrm{~Hz}, \mathrm{H} 2 \mathrm{~b}), 2.77-2.92(2 \mathrm{H}$, $250 \mathrm{~m}, \mathrm{H} 3), 6.99$ (1H, s, H4 or H7), $6.95(1 \mathrm{H}, \mathrm{s}, \mathrm{H} 4$ or H7), $1.26(3 \mathrm{H}, \mathrm{d}$, $\left.251 \mathrm{~J}=7.6 \mathrm{~Hz}, 1-\mathrm{C}_{3}\right), 2.28\left(6 \mathrm{H}, \mathrm{s}, 5-\right.$ and $\left.6-\mathrm{C}_{3} \mathrm{CO}\right)$.

252 Compound 15. HR-ESIMS $\left[\mathrm{M}+\mathrm{Na}^{+}\right.$calcd for $\mathrm{C}_{16} \mathrm{H}_{16} \mathrm{O}_{4} \mathrm{Na}$ 253 295.0946, found 295.0986, and $[2 \mathrm{M}+\mathrm{Na}]^{+}$calcd for $\mathrm{C}_{32} \mathrm{H}_{32} \mathrm{O}_{8} \mathrm{Na}$ 254 567.1995, found 567.2003; ${ }^{1} \mathrm{H}$ NMR $\left(\mathrm{CD}_{3} \mathrm{OD}\right) \delta 3.21(1 \mathrm{H}$, dquint, $J$ $255=8.8$ and $7.0 \mathrm{~Hz}, \mathrm{H1}), 1.99-2.08(1 \mathrm{H}, \mathrm{m}, \mathrm{H} 2 \mathrm{a}), 2.20(1 \mathrm{H}, \mathrm{ddd}, J=$ $25612.0,7.0$, and $1.2 \mathrm{~Hz}, \mathrm{H} 2 \mathrm{~b}), 4.38(1 \mathrm{H}, \mathrm{brd}, J=8.0 \mathrm{~Hz}, \mathrm{H} 3), 6.60(1 \mathrm{H}$, $257 \mathrm{~d}, J=8.0 \mathrm{~Hz}, \mathrm{H} 6), 6.73(1 \mathrm{H}, \mathrm{d}, J=8.0 \mathrm{~Hz}, \mathrm{H} 7), 1.25(1 \mathrm{H}, \mathrm{d}, J=7.0$ $\left.258 \mathrm{~Hz}, 1-\mathrm{CH}_{2}\right), 6.49\left(1 \mathrm{H}, \mathrm{d}, J=1.7 \mathrm{~Hz}, \mathrm{H} 2^{\prime}\right), 6.66(1 \mathrm{H}, \mathrm{d}, J=8.0 \mathrm{~Hz}$, $\left.259 \mathrm{H5}^{\prime}\right), 6.44\left(1 \mathrm{H}, \mathrm{dd}, J=8.0\right.$ and $\left.1.7 \mathrm{~Hz}, \mathrm{H}^{\prime}\right)$.

260 Compound 16. HR-ESIMS $[\mathrm{M}+\mathrm{Na}]^{+}$calcd for $\mathrm{C}_{16} \mathrm{H}_{16} \mathrm{O}_{4} \mathrm{Na}$ 261 295.0946, found 295.0964; ${ }^{1} \mathrm{H}$ NMR $\left(\mathrm{CD}_{3} \mathrm{OD}\right) \delta 3.08(1 \mathrm{H}$, sext, $J=$ $2627.5 \mathrm{~Hz}, \mathrm{H} 1), 1.55(1 \mathrm{H}, \mathrm{dt}, J=12.4$ and $7.5 \mathrm{~Hz}, \mathrm{H} 2 \mathrm{a}), 2.75(1 \mathrm{H}, \mathrm{dt}, J$ $263=12.4$ and $7.5 \mathrm{~Hz}, \mathrm{H} 2 \mathrm{~b}), 4.24(1 \mathrm{H}, \mathrm{t}, J=7.5 \mathrm{~Hz}, \mathrm{H} 3), 6.61(1 \mathrm{H}, \mathrm{d}, J$ $264=8.0 \mathrm{~Hz}, \mathrm{H} 6), 6.73(1 \mathrm{H}, \mathrm{d}, J=8.0 \mathrm{~Hz}, \mathrm{H} 7), 1.26(3 \mathrm{H}, \mathrm{d}, J=7.5 \mathrm{~Hz}$, $\left.2651-\mathrm{CH}_{3}\right), 6.60\left(1 \mathrm{H}, \mathrm{d}, J=2.0 \mathrm{~Hz}, \mathrm{H} 2^{\prime}\right), 6.70\left(1 \mathrm{H}, \mathrm{d}, J=8.0 \mathrm{~Hz}, \mathrm{H} 5^{\prime}\right)$, $2666.55\left(1 \mathrm{H}, \mathrm{dd}, J=8.0\right.$ and $\left.2.0 \mathrm{~Hz}, \mathrm{H} 6^{\prime}\right)$.

267 Compound 17. HR-ESIMS $[\mathrm{M}+\mathrm{Na}]^{+}$calcd for $\mathrm{C}_{18} \mathrm{H}_{18} \mathrm{O}_{4} \mathrm{Na}$ 268321.1103 , found 321.1137, and $[2 \mathrm{M}+\mathrm{Na}]^{+}$calcd for $\mathrm{C}_{36} \mathrm{H}_{36} \mathrm{O}_{8} \mathrm{Na}$ 269 619.2308, found 619.2301; ${ }^{1} \mathrm{H}$ NMR $\left(\mathrm{CDCl}_{3}\right)$ of tetraacetate of $17, \delta$ $2702.81(1 \mathrm{H}, \mathrm{dq}, J=7.8$ and $6.8 \mathrm{~Hz}, \mathrm{H1}), 2.55(1 \mathrm{H}, \mathrm{dt}, J=1.6$ and 7.8 $271 \mathrm{~Hz}, \mathrm{H} 2), 6.92(1 \mathrm{H}, \mathrm{s}, \mathrm{H} 4), 6.90(1 \mathrm{H}, \mathrm{s}, \mathrm{H} 7), 1.35(3 \mathrm{H}, \mathrm{d}, J=6.8 \mathrm{~Hz}$, $\left.2721-\mathrm{C}_{3}\right), 1.54\left(3 \mathrm{H}, \mathrm{s}, 3-\underline{\mathrm{C}}_{3}\right), 7.15\left(1 \mathrm{H}, \mathrm{s}, \mathrm{H} 2^{\prime}\right), 7.00\left(1 \mathrm{H}, \mathrm{s}, \mathrm{H} 5^{\prime}\right)$, $2733.23\left(1 \mathrm{H}, \mathrm{dd}, J=16.2\right.$ and $\left.7.8 \mathrm{~Hz}, 7^{\prime} \beta-\mathrm{C}_{2}\right), 2.82(1 \mathrm{H}, \mathrm{brd}, J=16.2$ $\left.274 \mathrm{~Hz}, 7^{\prime} \alpha-\mathrm{CH}_{2}\right), 2.25$ (6H, s, 5-, 6-, 3'-, or $\left.4^{\prime}-\mathrm{C}_{\underline{3}} \mathrm{CO}\right), 2.27$ (3H, s, 5-, $2756^{6}-, 3^{\prime}$-, or $\left.4^{\prime}-\mathrm{CH}_{3} \mathrm{CO}\right), 2.30\left(3 \mathrm{H}, \mathrm{s}, 5-, 6^{-}, 3^{\prime}\right.$-, or $\left.4^{\prime}-\mathrm{C}_{3} \mathrm{CO}\right)$. 276 Observed NOESY correlations from $\mathrm{H} 2$ to $1-\mathrm{CH}_{3}, 3-\mathrm{CH}_{3}$, and $7^{\prime} \alpha$ $277 \mathrm{C}_{2} \alpha$, and $7^{\prime} \beta-\underline{\mathrm{C}}_{2}$; from $\mathrm{H} 7$ to $1-\mathrm{CH}_{3}$; from $1-\underline{\mathrm{C}}_{3}$ to $\mathrm{H} 2$ and $\mathrm{H} 7$; 278 from $7^{\prime} \beta-\underline{\mathrm{C}}_{2}$ to $3-\mathrm{C}_{3}$; from $3-\mathrm{C}_{\underline{3}}$ to $\mathrm{H} 2,7^{\prime} \beta-\underline{\mathrm{C}}_{2},{ }_{2}, \mathrm{H} 4$, and $\mathrm{H} 2^{\prime}$; 279 and from $\mathrm{H}_{2}^{\prime}$ to $3-\mathrm{CH}_{3}$.
Compound 18. HR-ESIMS $[\mathrm{M}+\mathrm{Na}]^{+}$calcd for $\mathrm{C}_{18} \mathrm{H}_{18} \mathrm{O}_{4} \mathrm{Na} 280$ 321.1103, found 321.1133, and $[2 \mathrm{M}+\mathrm{Na}]^{+}$calcd for $\mathrm{C}_{36} \mathrm{H}_{36} \mathrm{O}_{8} \mathrm{Na} 281$ 619.2308, found 619.2295; ${ }^{1} \mathrm{H}$ NMR $\left(\mathrm{CDCl}_{3}\right)$ of tetraacetate of 18, 282 $3.04\left(2 \mathrm{H}, \mathrm{dq}, J=4.8\right.$ and $7.0 \mathrm{~Hz}, \mathrm{H} 1$ and $\left.\mathrm{H}^{\prime}\right), 2.61(1 \mathrm{H}, \mathrm{dt}, J=8.6283$ and $4.8 \mathrm{~Hz}, \mathrm{H} 2), 4.64(1 \mathrm{H}, \mathrm{d}, J=8.6 \mathrm{~Hz}, \mathrm{H} 3), 6.95(2 \mathrm{H}, \mathrm{s}, \mathrm{H} 4$ and 284 $\left.\mathrm{H}^{\prime}\right), 7.11\left(2 \mathrm{H}, \mathrm{s}, \mathrm{H} 7\right.$ and $\left.\mathrm{H}^{\prime}\right), 1.32\left(6 \mathrm{H}, \mathrm{d}, J=7.0 \mathrm{~Hz}, 1-\mathrm{CH}_{3}\right.$ and 285 $\left.7^{\prime}-\mathrm{CH}_{3}\right), 2.26\left(6 \mathrm{H}, \mathrm{s}, 5-, 6-, 3^{\prime}\right.$-, or $\left.4^{\prime}-\mathrm{CH}_{3} \mathrm{CO}\right), 2.28(6 \mathrm{H}, \mathrm{s}, 5-, 6$-, 286 $3^{\prime}$-, or $\left.4^{\prime}-\mathrm{CH}_{3} \mathrm{CO}\right)$. Observed NOE from $1-$ and $7^{\prime}-\mathrm{C}_{3}$ to $\mathrm{H} 2$ and 287 $\mathrm{H} 3$ in NOE difference spectra. 288

Measurement of the Xanthine Oxidase Inhibitory Activities 289 of the Isolated Compounds. The xanthine oxidase inhibition assay 290 was performed according to a previously reported protocol. ${ }^{17}$ Briefly, 291 a reaction medium consisting of $10 \mu \mathrm{L}$ of $1 \mathrm{mmol} / \mathrm{L}$ xanthine in 292 DMSO, $10 \mu \mathrm{L}$ of the test sample $(6 \mathrm{mg} / \mathrm{mL}$ for thermal products and 293 $4 \mathrm{mmol} / \mathrm{L}$ for isolated compounds) in DMSO, and $160 \mu \mathrm{L}$ of 12.5294 $\mathrm{mmol} / \mathrm{L}$ phosphate buffer $(\mathrm{pH} 7.4)$ was preincubated at $37{ }^{\circ} \mathrm{C}$ for 5295 min. To this solution, $20 \mu \mathrm{L}$ of $0.027 \mathrm{unit} / \mathrm{mL} \mathrm{XO}$ buffer solution was 296 added. After incubation at $37{ }^{\circ} \mathrm{C}$ for $10 \mathrm{~min}, 3 \% \mathrm{HClO}_{4}(\mathrm{aq})(25 \mu \mathrm{L}) 297$ was added to quench the reaction. An aliquot of the solution $(20 \mu \mathrm{L}) 298$ was injected into the HPLC column to quantify the uric acid 299 production (Mightysil RP-18 GP Aqua column, Kanto Chemical, 300 Tokyo Japan; $250 \times 4.6 \mathrm{~mm}$ i.d., $5 \mu \mathrm{m}$; flow rate, $1.0 \mathrm{~mL} / \mathrm{min} ; 301$ solvent, 2.5:97.5 methanol-0.1\% phosphoric acid in water; detection 302 at $290 \mathrm{~nm}$; temperature, $35{ }^{\circ} \mathrm{C}$ ). The percent inhibition was 303 calculated according to the following equation: inhibition (\%) $=304$ [(peak area of uric acid in control experiment) - (peak area of uric 305 acid in sample experiment)]/(peak area of uric acid in control 306 experiment) $\times 100$.

307

Statistical Analysis. Activity data obtained from the experiments 308 in triplicate are presented as means \pm standard error (SE). The 309 differences in the data between samples and control experiments were 310 evaluated by the Dunnett's test. A $p$-value $<0.05$ was considered 311 statistically significant.

RESULTS AND DISCUSSION 313

HPLC Analysis of the Thermal Reaction Products of 314 Caffeic Acid at Various Temperatures. In our previous 315 work, we observed a model roasting reaction product of 316 chlorogenic acid having XO inhibitory activity, whereas intact 317 chlorogenic acid did not inhibit XO activity. We also examined 318 the XO inhibitory activities of the thermally treated caffeic and 319 quinic acids, which are both components of chlorogenic acid. ${ }^{20} 320$ The results revealed that the XO inhibitory activity of the 321 thermal reaction product of caffeic acid was greater than that of 322 chlorogenic acid, whereas no XO inhibitory activity was 323 observed for the product of quinic acid. Therefore, in this 324 investigation the thermal reaction of caffeic acid was further 325 investigated for the production of XO inhibitors and enhanced 326 $\mathrm{XO}$ inhibitory activity. The high-temperature thermal treat- 327 ment of caffeic acid was carried out through a model roasting 328 reaction according to a previously reported method with 10:28 329 caffeic acid-solid support (a phosphoric salt). ${ }^{20}$ The XO 330 inhibitory activities of the thermal treatment products at 331 different temperatures are illustrated in Figure 1. Intact caffeic $332 \mathrm{fl}$ acid has weak XO inhibitory activity (22\% inhibition) at the 333 examined concentration $(0.3 \mathrm{mg} / \mathrm{mL})$, whereas the $\mathrm{XO} 334$ inhibitory activities of the thermal reaction products were 335 greater than those of caffeic acid. The activity increased with 336 increasing reaction temperature up to $170{ }^{\circ} \mathrm{C}$, after which it 337 decreased gradually up to $290^{\circ} \mathrm{C}$. Figure 2A (Figure S1A in $338 \mathrm{f2}$ the Supporting Information) displays the HPLC data 339 representing the constituents of the thermal reaction products 340 obtained by gradient elution on an octadecylsilyl silica gel 341 (ODS) analytical column with 5 to $100 \%$ acetonitrile. At a 342 reaction temperature of $110^{\circ} \mathrm{C}$, the only noticeable peak was 343 that of the starting material at a retention time of $15.5 \mathrm{~min} .344$ 


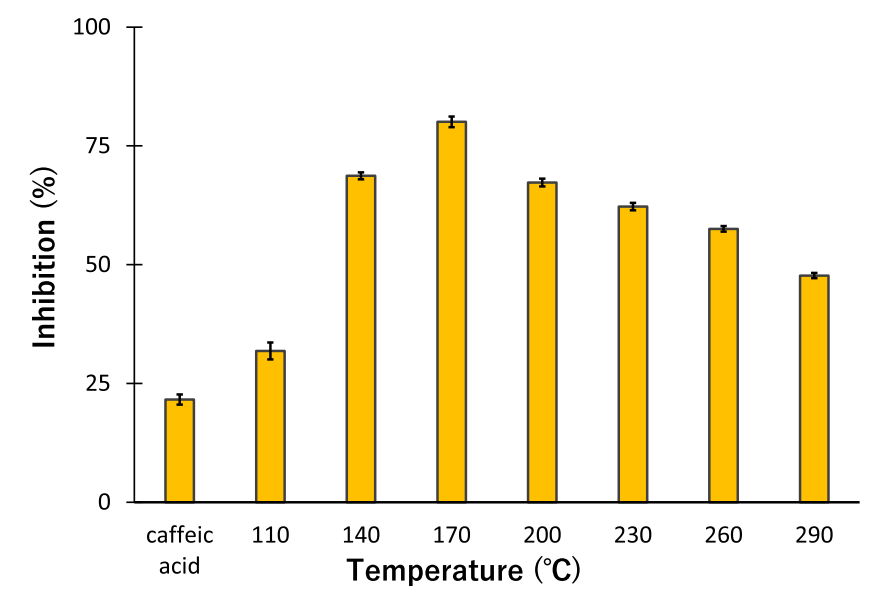

Figure 1. Xanthine oxidase inhibitory activities of the thermal reaction products $(0.3 \mathrm{mg} / \mathrm{mL})$ of caffeic acid. Data are expressed as the means $\pm \operatorname{SE}(n=3)$.

345 When the temperature was increased to 140 and $170{ }^{\circ} \mathrm{C}$, 346 numerous peaks were observed in the retention time range of 34719 to $42 \mathrm{~min}$, along with the peak corresponding to caffeic acid 348 (retention time of $15.5 \mathrm{~min}$ ), with very complex peaks 349 observed at $28-42 \mathrm{~min}$. With a further increase in temperature 350 to $200{ }^{\circ} \mathrm{C}$, the caffeic acid peak and the peaks at 19-22 min 351 disappeared. Moreover, the intensities of the complex peaks at 352 30-42 min were lower than those observed at $170{ }^{\circ} \mathrm{C}$. On the 353 other hand, a new peak appeared at the retention time of 11.6 $354 \mathrm{~min}$ for the reactions at temperatures of $200{ }^{\circ} \mathrm{C}$ or greater. At 355 temperatures over $230{ }^{\circ} \mathrm{C}$, almost all peaks gradually 356 disappeared, except for the major peak at $11.6 \mathrm{~min}$ and a 357 minor peak at $27.0 \mathrm{~min}$. Figure 2B (Figure $\mathrm{S} 1 \mathrm{~B}$ in the 358 Supporting Information) presents GPC data on the acetylated 359 products from the thermal reactions of caffeic acid. Under the 360 employed GPC conditions, acetylated caffeic acid $(0.26 \mathrm{kDa})$, 361 which was obtained from caffeic acid by treatment with acetic 362 anhydride and pyridine, was detected at a retention time of $36310.8 \mathrm{~min}$. The area of the earlier eluting peak increased with 364 increasing reaction temperature up to $200{ }^{\circ} \mathrm{C}$. This peak was 365 clearly observed at $10.1 \mathrm{~min}$ (corresponding to $0.7 \mathrm{kDa}$, 366 calculated from the top of the peak) for the reaction at $170{ }^{\circ} \mathrm{C}$, 367 and it broadened to a retention time of $9 \mathrm{~min}$ at $200{ }^{\circ} \mathrm{C}$, which 368 indicated that higher-weight molecules (up to $\mathrm{sa} 0.3 \mathrm{kDa}$ ) 369 were produced by the elevation of the reaction temperature. In 370 the GPC data of the reactions at $230{ }^{\circ} \mathrm{C}$ or above, the peak was 371 further broadened between the retention times of 8.5 and 12 $372 \mathrm{~min}$, and two new peaks at retention times of 11.1 and 11.5 $373 \mathrm{~min}$ were also observed, which indicated that low-molecular374 weight degradation products (below $0.3 \mathrm{kDa}$ ) were produced 375 along with higher-weight compounds (up to ca. $6 \mathrm{kDa}$ ). 376 Considering the data from constituent analysis (Figures 2A 377 and S1A) and molecular size analysis (Figures 2 B and S1B) 378 and the data on the $\mathrm{XO}$ inhibitory activities of the products 379 from the reactions at various temperatures (Figure 1), it was 380 determined that the $\mathrm{XO}$ inhibitory activities of moderate381 molecular-weight compounds (3-0.3 kDa by GPC analysis), 382 which may be coupling products of caffeic acid, should be 383 stronger than that of caffeic acid. Additionally, these 384 compounds might contribute toward the enhanced $\mathrm{XO}$ 385 inhibitory activities of the products obtained at $170{ }^{\circ} \mathrm{C}$. On 386 the other hand, higher-molecular-weight products, produced in 387 the reactions at and above $200{ }^{\circ} \mathrm{C}$ and eluted earlier from the
GPC column, might exhibit weak XO inhibition. Finally, the 388 low-molecular-weight products, observed as peaks eluted later 389 from the GPC column from the reactions at high temperatures, 390 may also present weak XO inhibitory activities. Thus, the 391 accumulation of both the higher- and lower-molecular-weight 392 products should reduce the XO inhibitory activities of the 393 reaction products produced at and above $200{ }^{\circ} \mathrm{C}$. From the 394 constituent analysis data of the products obtained at various 395 temperatures (Figures 2A and S1A), moderate-molecular- 396 weight products, which are predicted to be strong XO 397 inhibitors, should correspond to the peaks in the retention 398 time range of 19 to $42 \mathrm{~min}$ in the HPLC data of the reactions 399 at $140-200{ }^{\circ} \mathrm{C}$.

Isolation and Structure Identification of the Con- 401 stituent Compounds Obtained from Thermal Reactions 402 at $\mathbf{1 4 0 - 2 0 0}{ }^{\circ} \mathrm{C}$. To identify the compounds that correspond 403 to the peaks observed in the HPLC constituent analysis of the 404 products obtained at $140-200{ }^{\circ} \mathrm{C}$, isolation and structure 405 identification of the constituents of the thermal reaction 406 products were carried out. Multiple large scale thermal 407 reactions of caffeic acid were performed at 140 and $200{ }^{\circ} \mathrm{C} ; 408$ in total, 18 compounds were purified from the reaction 409 products, as described in the Materials and Methods section. 410 The isolated compounds $\mathbf{1 - 4}, \mathbf{7}$, and 8 were identical to the 411 previously identified phenylindanes according to their NMR 412 and MS data (Figure 3). ${ }^{20}$ Compounds $\mathbf{1 5}$ and $\mathbf{1 6}$ were $413 \mathrm{f} 3$ determined to be other phenylindane compounds that had 414 been previously identified by Frank et al. ${ }^{13}$ Compounds 11 and 415 12 were determined to be catechol and 4-ethylcatechol, which 416 are reportedly found in roasted coffee. ${ }^{21}$ The structures of 417 compounds 5, 6, and $\mathbf{1 4}$ were also identified, as shown in 418 Figure 3, by comparing the NMR and MS data to previously 419 reported data. ${ }^{22-24}$ Notably, compounds 9, 10, 13, 17, and 18420 were compounds newly identified in this work, and their 421 structures were elucidated by NMR and MS analyses. 422

High-resolution mass spectrometry (HR-MS) data of 423 compounds $\mathbf{9}$ and $\mathbf{1 0}$ indicated that they were constitutional 424 isomers with the molecular formula $\mathrm{C}_{24} \mathrm{H}_{24} \mathrm{O}_{6}$ (9: $\mathrm{m} / z 425$ 409.1656 $[\mathrm{M}+\mathrm{H}]^{+}$and 10: $\mathrm{m} / z$ 409.1652 $\left.[\mathrm{M}+\mathrm{H}]^{+}\right)$. The 426 ${ }^{1} \mathrm{H}$ NMR spectra of $\mathbf{9}$ and $\mathbf{1 0}$ were also very similar, indicating 427 that they were stereoisomers, as summarized in Table S1 428 (Supporting Information). The ${ }^{1} \mathrm{H}$ NMR spectrum of 9429 revealed seven aromatic proton signals at 6.60, 6.67, and 6.72430 $\mathrm{ppm}$ in the same coupling system and at $6.19,6.20,6.66$, and 431 $6.77 \mathrm{ppm}$ as singlet shapes. The former peaks indicated the 432 existence of a trisubstituted benzene ring with protons 433 arranged in a 1,2,4 configuration, whereas the latter peaks 434 revealed the presence of two tetra-substituted benzene rings 435 with protons oriented para to one other; these systems were 436 derived from the aromatic moiety of caffeic acid. The HH- 437 COSY data of 9 clarified two coupling systems, consisting of 438 $\mathrm{CH}_{3}\left(\delta 1.21,1-\mathrm{CH}_{3}\right)-\mathrm{CH}(\delta 3.19, \mathrm{H} 1)-\mathrm{CH}_{2}(\delta 2.05, \mathrm{H} 2)-439$ $\mathrm{CH}\left(\delta\right.$ 4.49, H3) and $\mathrm{CH}_{3}\left(\delta 1.56,1^{\prime \prime}-\mathrm{CH}_{3}\right)-\mathrm{CH}(\delta 4.29,440$ $\left.\mathrm{H}^{\prime \prime}\right)$. The HMBC spectrum of 9 showed correlations from 441 $\mathrm{C} 1$ a to $\mathrm{H} 1$, from $\mathrm{C} 3 \mathrm{a}$ to $\mathrm{H} 3$, from $\mathrm{C} 1$ to $\mathrm{H} 7$, from $\mathrm{C} 3$ to $\mathrm{H} 4442$ and $\mathrm{H}_{2}$ ', from $\mathrm{C} 4$ to $\mathrm{H} 3$, from $\mathrm{C} 7$ to $\mathrm{H} 1$, and from $\mathrm{C}^{\prime}$ to $\mathrm{H} 3,443$ as shown in Figure 4, indicating the existence of a $444 \mathrm{f4}$ phenylindane structure consisting of two tetra-substituted 445 benzene rings and the $\mathrm{CH}_{3}-\mathrm{CH}-\mathrm{CH}_{2}-\mathrm{CH}$ system. Other 446 $\mathrm{C}-\mathrm{H}$ long range correlations were observed from $\mathrm{C1}^{\prime \prime}$ to $\mathrm{H}^{\prime}, 447$ $\mathrm{H} 3^{\prime \prime}, \mathrm{H}^{\prime \prime}$, and $1^{\prime \prime}-\mathrm{CH}_{3}$; from $\mathrm{C}^{\prime \prime}$ to $\mathrm{H}^{\prime \prime}$ and $1^{\prime \prime}-\mathrm{CH}_{3}$; from 448 $\mathrm{C}^{\prime \prime}$ to $\mathrm{H}^{\prime \prime}$; and from $1^{\prime \prime}-\mathrm{CH}_{3}$ to $\mathrm{H}^{\prime \prime}$ between the $\mathrm{CH}_{3}-\mathrm{CH} 449$ system and a trisubstituted benzene. Correlations were also 450 
A

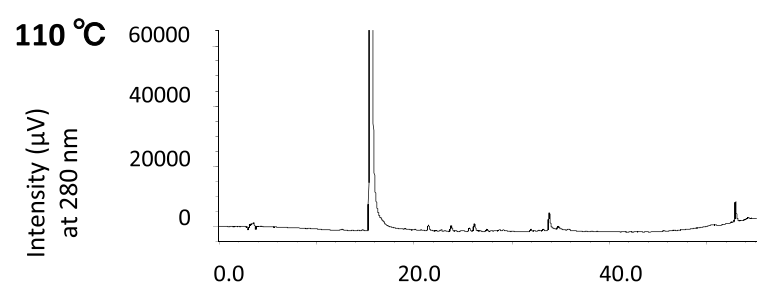

$140{ }^{\circ} \mathrm{C}$

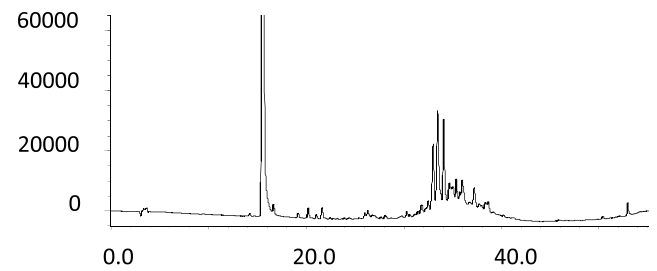

$170^{\circ} \mathrm{C}$

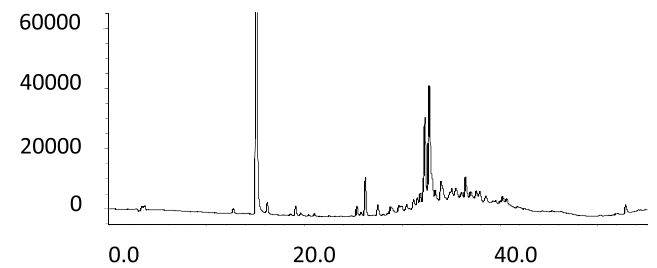

$200{ }^{\circ} \mathrm{C}$

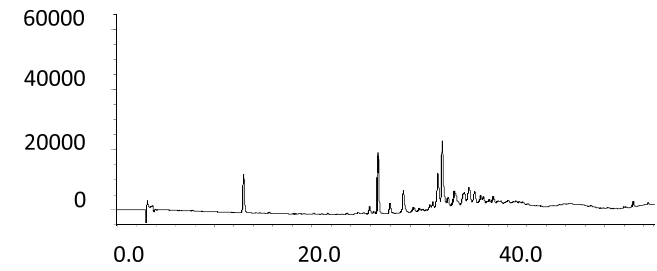

$230{ }^{\circ} \mathrm{C}$

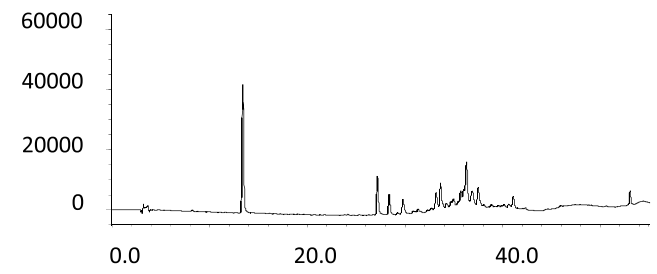

$260^{\circ} \mathrm{C}$

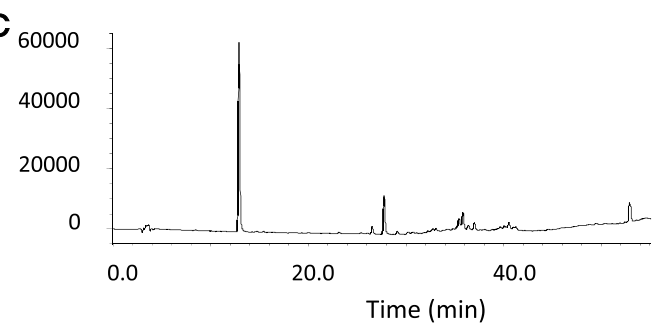

B

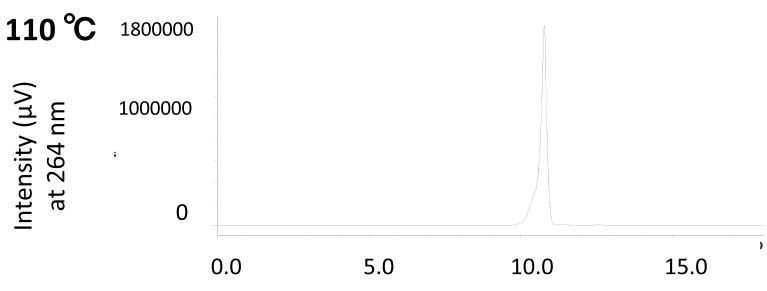

$140{ }^{\circ} \mathrm{C}$

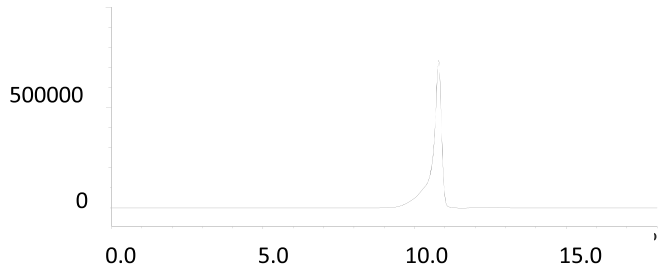

$170{ }^{\circ} \mathrm{C}$

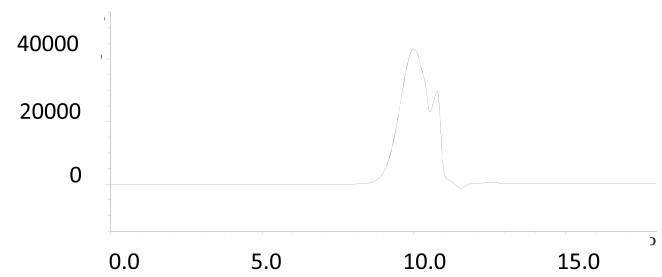

$200^{\circ} \mathrm{C}$

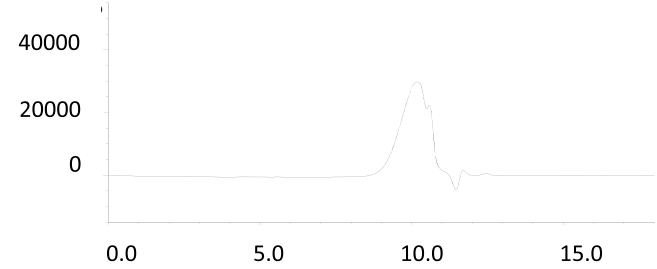

$230{ }^{\circ} \mathrm{C}_{40000}$

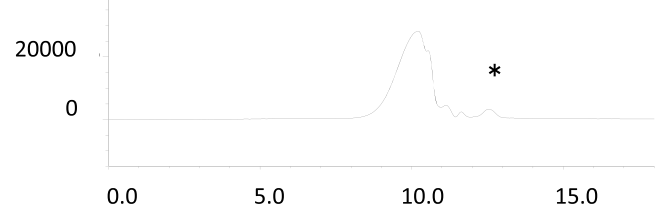

$260^{\circ} \mathrm{C}$

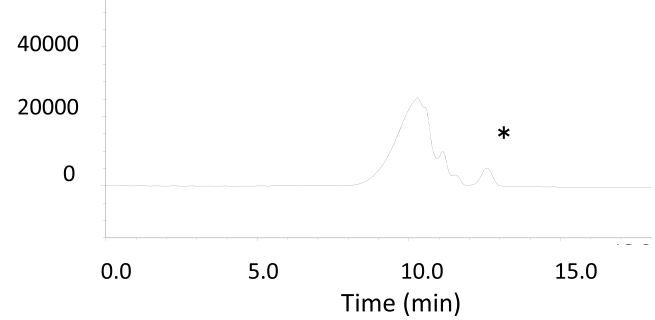

* Pyridine from acetylation reaction

Figure 2. Selected HPLC analytical data of various thermal reaction products of caffeic acid. (A) Chromatograms obtained using an octadecylsilyl silica gel (ODS) column. (B) Chromatograms obtained using a gel permeation chromatography (GPC) column.

451 observed from $\mathrm{Cl}^{\prime}$ to $\mathrm{H}^{\prime \prime}$ and from $\mathrm{C6}^{\prime}$ to $\mathrm{H}^{\prime \prime}$ and $1^{\prime \prime}-\mathrm{CH}_{3}$ 452 between the $\mathrm{CH}_{3}-\mathrm{CH}$ system and one of the tetra-substituted ${ }_{453}$ benzenes, as shown in Figure 4. These results indicated that an 454 ethylcatechol structure was attached to the $6^{\prime}$-position of the tetra-substituted benzene at the 3-position of the indane ${ }_{455}$ substructure. The stereochemistry of the three chiral carbons ${ }_{456}$ was deduced from the observed NOE correlations in the ${ }_{457}$ NOESY spectrum of 9 . Strong correlations between $\mathrm{H} 1$ and 458 


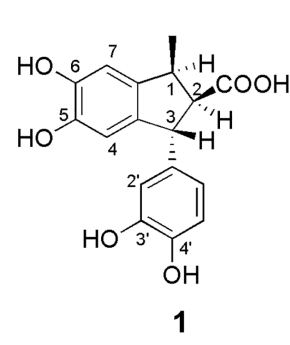<smiles>C[C@H]1c2cc(O)c(O)cc2[C@H](c2ccc(O)c(O)c2)[C@H]1C(=O)O</smiles><smiles>O=C(O)C1=Cc2cc(O)c(O)cc2C12CCCC2C(=O)O</smiles><smiles>CC1c2cc(O)c(O)cc2C(C)c2cc(O)c(O)cc21</smiles><smiles>CC(c1ccc(O)c(O)c1)c1ccc(O)c(O)c1</smiles><smiles>C[C@H]1C[C@H](C)c2cc(O)c(O)cc21</smiles>

7<smiles>C[C@H]1C[C@H](c2ccc(O)c(O)c2)c2cc(O)c(O)cc21</smiles>

8<smiles>C[C](c1ccc(O)c(O)c1)c1cc(O)c(O)cc1[C@@H]1c2cc(O)c(O)cc2[C@@H](C)C[C@H]1C</smiles>

9<smiles>C[C@H]1C[C@H](c2cc(O)c(O)cc2[C@H](C)c2ccc(O)c(O)c2)c2cc(O)c(O)cc21</smiles>

10<smiles>Oc1ccccc1O</smiles>

11<smiles>CCc1ccc(O)c(O)c1</smiles>

12<smiles>CC(c1ccc(O)c(O)c1)c1cccc(O)c1O</smiles>

13<smiles>CC1CCc2cc(O)c(O)cc21</smiles>

14

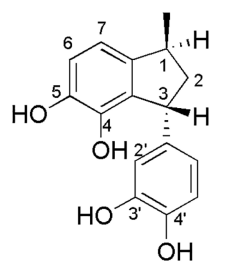

15<smiles>C[C@H]1C[C@H](c2ccc(O)c(O)c2)c2c1ccc(O)c2O</smiles>

16

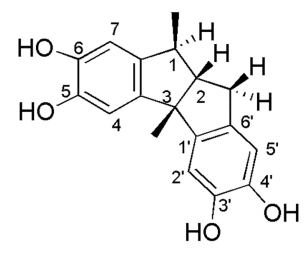

17

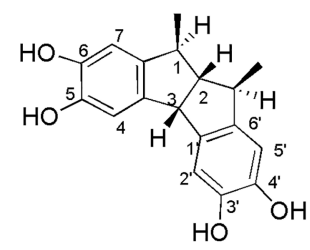

18

Figure 3. Chemical structures of the identified constituent compounds of the thermal reaction products of caffeic acid. Tentative positional numbering is based on the numbering systems of indane and substituted benzene rings.
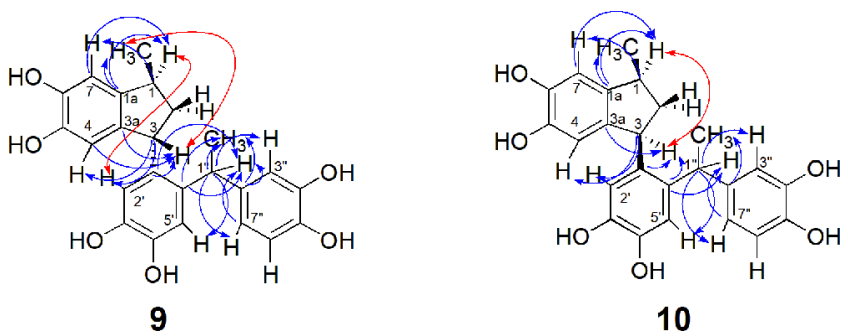

Figure 4. Selected HMBC and NOESY correlations observed in compounds 9 and $\mathbf{1 0}$. Blue arrows indicate long range $\mathrm{C}-\mathrm{H}$ coupling, and red double-headed arrows indicate NOE.

$459 \mathrm{H}^{\prime}$ and between $\mathrm{H} 3$ and $1-\mathrm{CH}_{3}$ revealed the trans460 relationship of the methyl group at the 1-position and the 461 phenyl group at the 3-position. The stereochemistry of $\mathrm{Cl}^{\prime \prime}$ 462 could not be deduced from its NMR data because of its flexible 463 structure. Thus, the structure of $\mathbf{9}$ was determined as depicted 464 in Figure 3.

465 The ${ }^{1} \mathrm{H}$ and ${ }^{13} \mathrm{C}$ NMR data of 10, including correlations in 466 the COSY and HMBC spectra, were very similar to those of 9 467 (Table S1 in the Supporting Information and Figure 4), 468 indicating that the planar structure of $\mathbf{1 0}$ was the same as that 469 of 9 . Differences in the stereochemistry of 10 were deduced by 470 NOESY. The observed NOE between $\mathrm{H} 1$ and $\mathrm{H} 3$ in the 471 NOESY spectrum of $\mathbf{1 0}$ revealed that the methyl group at the 472 1-position and the phenyl group at the 3-position were cis 473 relative to one another. Similar to 9 , the stereochemistry at the $4741^{\prime \prime}$-position could not be elucidated; thus, the structure of 475 compound $\mathbf{1 0}$ was determined as depicted in Figure 3.
The HR-MS data of compound 13 revealed a molecular- 476 related ion at $m / z 269.0816$ (calcd for $\mathrm{C}_{14} \mathrm{H}_{14} \mathrm{O}_{4} \mathrm{Na}, 477$ 269.0790), indicating the molecular formula $\mathrm{C}_{14} \mathrm{H}_{14} \mathrm{O}_{4}, 478$ which is the same as that of compound 6. The NMR data of 479 the tetra-acetylated derivative of $\mathbf{1 3}$ (13a) showed the presence 480 of a $\mathrm{CH}_{3}-\mathrm{CH}$ unit $(4.25(1 \mathrm{H}, \mathrm{q}, J=7.0 \mathrm{~Hz}), 1.57(3 \mathrm{H}, \mathrm{d}, J=481$ $7.0 \mathrm{~Hz})$ ) and six aromatic protons, which were very similar to 482 those of 6. A signal for an aromatic proton having two ortho- 483 couplings $(7.23(1 \mathrm{H}, \mathrm{dd}, J=8.6$ and $8.2 \mathrm{~Hz}))$ and signals of 484 four phenolic acetyl groups indicated that $\mathbf{1 3}$ was a regioisomer 485 of 6 in reference to the attached position of the $\mathrm{CH}_{3}-\mathrm{CH}$ unit 486 as shown in Figure 3.

The HR-MS data of compounds $\mathbf{1 7}$ and $\mathbf{1 8}$ indicated that 488 both molecular formulas were the same, $\mathrm{C}_{18} \mathrm{H}_{18} \mathrm{O}_{14}(17: m / z 489$ $321.1137[\mathrm{M}+\mathrm{Na}]^{+}, \mathbf{1 8}: \mathrm{m} / z 321.1133[\mathrm{M}+\mathrm{Na}]^{+}$, both 490 calculated for $\left.\mathrm{C}_{18} \mathrm{H}_{18} \mathrm{O}_{4} \mathrm{Na}, 321.1103\right)$. The ${ }^{1} \mathrm{H}$ NMR 491 spectrum of $17 \mathrm{a}$, which was obtained from 17 by reaction 492 with acetic anhydride in pyridine, showed four signals for 493 phenolic acetyl groups at $2.25(3 \mathrm{H}, \mathrm{s} \times 2), 2.27(3 \mathrm{H}, \mathrm{s})$, and 494 $2.30(3 \mathrm{H}, \mathrm{s}) \mathrm{ppm}$ and four singlet aromatic proton signals at 495 $6.90,6.92,7.00$, and $7.15 \mathrm{ppm}$, indicating the presence of two 496 sets of 1,2,4,5-tetra-substituted benzene rings derived from two 497 molecules of caffeic acid. The HH-COSY of $17 \mathbf{a}$ revealed the 498 presence of a $\mathrm{CH}_{3}(1.35 \mathrm{ppm})-\mathrm{CH}(2.81 \mathrm{ppm})-\mathrm{CH}(2.55499$ $\mathrm{ppm})-\mathrm{CH}_{2}$ (2.82 and $\left.3.23 \mathrm{ppm}\right)$ coupling system, which was 500 adjacent to the aromatic rings. Another singlet signal (1.54 501 ppm) due to a methyl group adjacent to a quaternary carbon 502 was also observed. These data indicated that $\mathbf{1 7}$ comprised a 503 bicyclo[3.3.0] octane structure appended with two dihydrox- 504 ybenzene rings and two methyl groups. The stereochemistry 505 around the bicyclooctane rings was deduced by NOE 506 
507 correlations from $\mathrm{H} 2$ to the 1 - and 3-methyl protons in the 508 NOESY spectrum of $17 \mathbf{a}$, revealing the presence of cis 509 relations. Thus, the structure of $\mathbf{1 7}$ was determined as depicted 510 in Figure 3.

511 Although $\mathbf{1 7}$ and $\mathbf{1 8}$ presented the same molecular-related 512 peaks in their MS data, the ${ }^{1} \mathrm{H}$ NMR data of 18a (acetylated 513 derivative of 18) were much simpler than those of $17 \mathbf{a}$, 514 indicating that 18 was a symmetrical isomer of $\mathbf{1 7}$. The $\mathrm{HH}$ 515 COSY of $18 \mathbf{a}$ indicated the presence of a symmetrical coupling 516 system, $\left.\mathrm{CH}_{3}(1.32 \mathrm{ppm})-\mathrm{CH}(3.04 \mathrm{ppm})\right]_{2}-\mathrm{CH} \quad(2.61$ $517 \mathrm{ppm})-\mathrm{CH}(4.64 \mathrm{ppm})$, which was attached to two tetra518 substituted benzene rings. In addition to the above data, 519 proton signals due to four phenolic acetyl groups, $2.26(3 \mathrm{H} \times$ $5202)$ and $2.28(3 \mathrm{H} \times 2) \mathrm{ppm}$, and two sets of para-substituted 521 aromatic protons, $6.95(1 \mathrm{H} \times 2)$ and $7.11(1 \mathrm{H} \times 2)$, indicated 522 that 18 had a symmetrical bicyclo[3.3.0] octane structure 523 similar to that of 17 . NOEs were observed from 1- and $7^{\prime}-\mathrm{CH}_{3}$ 524 to $\mathrm{H} 2$ and $\mathrm{H} 3$ in the NOE difference spectra of 18 . Thus, the 525 structure of $\mathbf{1 8}$ was determined as depicted in Figure 3.

526 Structure-Based Classification of the Thermal Reac527 tion Products. The high-temperature treatment of caffeic acid 528 stimulates its decarboxylation to afford 4-vinylcatechol, which 529 is significantly more reactive than the parent caffeic acid. ${ }^{25}$ 530 Therefore, 4-vinylcatechol presents an important intermediate 531 of the thermally mediated reactions of caffeic acid. By 532 considering the structural differences of the constituent 533 compounds obtained from the thermal reactions, the identified 534 compounds were classified into three categories on the basis of 535 their vinylcatechol substructure: category I (compounds 1-4) 536 consists of the coupling products of vinylcatechol and caffeic 537 acid, category II (compounds 5, 7, 8, 9, 10, 15, and 16) 538 consists of the coupling products of two or three vinyl539 catechols, and category III (compounds 6, 13, 14, 17, and 18) 540 is composed of compounds formed by coupling with or 541 elimination of the catechol moiety (Figure 3). All the 542 categorized compounds were assigned to the observed peaks 543 in the HPLC chromatograms from the reactions at 140, 170, 544 and $200{ }^{\circ} \mathrm{C}$, as shown in Figure 5. The category I compounds 545 were observed in the $140{ }^{\circ} \mathrm{C}$ reaction product along with 546 caffeic acid and the category II compounds. The HPLC data of 547 the $170{ }^{\circ} \mathrm{C}$ reaction product indicated decreases in the 548 intensities of caffeic acid and the category I compounds. 549 Additionally, the region representing the category II com550 pounds (retention time of 30-40 $\mathrm{min}$ ) became more complex 551 compared with the same region in the chromatogram of the $552140{ }^{\circ} \mathrm{C}$ reaction product. This indicated that at the reaction 553 temperature of $170{ }^{\circ} \mathrm{C}$, various vinylcatechol oligomers were 554 additionally produced instead of the caffeic acid-vinylcatechol 555 compounds. Through consideration of the GPC analytical data 556 of the $170{ }^{\circ} \mathrm{C}$ reaction product (Figure $2 \mathrm{~B}$ ), it was determined 557 that the oligomerization degree of the newly produced 558 compounds might be higher than that of the compounds 559 observed in the $140{ }^{\circ} \mathrm{C}$ reaction product. At the reaction 560 temperature of $200{ }^{\circ} \mathrm{C}$, the category I compounds disappeared, 561 whereas the category III compounds were observed in addition 562 to the vinylcatechol oligomers (category II).

563 XO Inhibitory Activities of the Oligomeric Com564 pounds from the Thermal Reactions of Caffeic Acid. 565 Figure 6 illustrates the XO inhibitory activities of the isolated 566 constituents $(200 \mu \mathrm{mol} / \mathrm{L})$ of the thermal reaction products. 567 Although the starting material, caffeic acid, showed very weak 568 activity at the examined concentration, the isolated compounds 569 exerted stronger activities in the order $3>4>8,10,17>7,9$,
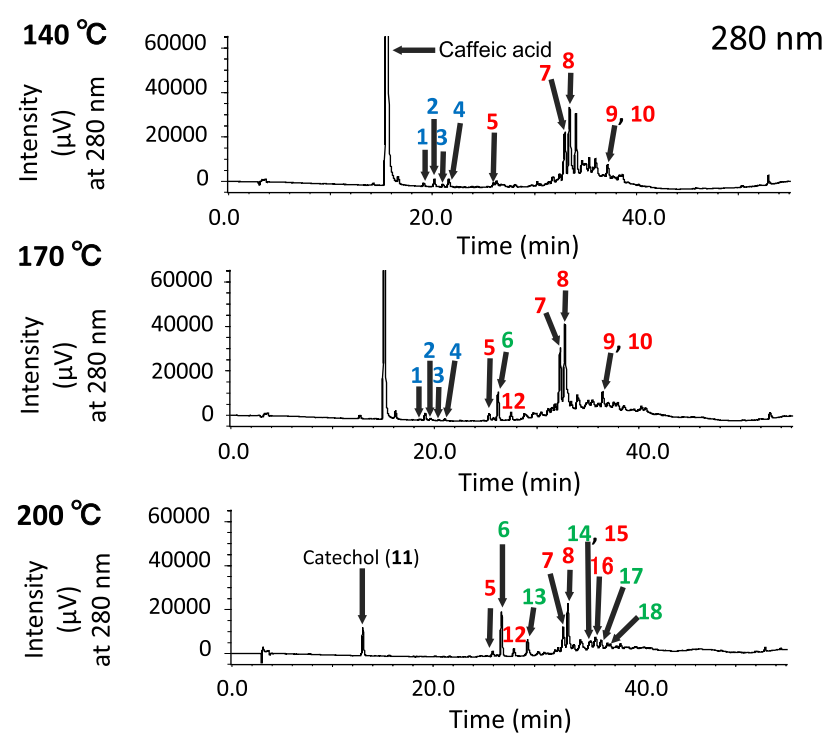

Figure 5. Peak assignments of the identified constituent compounds in the HPLC profiles of the thermal reaction products at 140,170 , and $200{ }^{\circ} \mathrm{C}$. Blue numbers, category I compounds (caffeic acidvinylcatechol coupled compounds); red numbers, category II compounds (vinylcatechol oligomers); green numbers, category III compounds.

$2,5,1,6>16,15,14,13$, on the basis of their percent 570 inhibition values. The compounds with the highest inhibition 571 levels, caffeic acid-vinylcatechol compounds 3 and 4, were 572 detected in the products of the 140 and $170{ }^{\circ} \mathrm{C}$ reactions but 573 were absent in the product of the $200{ }^{\circ} \mathrm{C}$ reaction. These were 574 followed by compounds 7, $\mathbf{8}$ (vinylcatechol dimers), and $\mathbf{1 0} 575$ (trimer), which were mainly observed in the products of the 576 reactions at 140 and $170{ }^{\circ} \mathrm{C}$. Conversely, the weakest 577 inhibitory compounds, 13 and 14, catechol-eliminated 578 compounds belonging to category III, were both observed 579 solely as the constituents of the product of the $200{ }^{\circ} \mathrm{C}$ reaction. 580

A comparison of the results of the $\mathrm{XO}$ inhibitory activities of 581 the identified compounds with those of the thermal reaction 582 products $\left(110-290{ }^{\circ} \mathrm{C}\right.$, Figure 1) indicated that caffeic acid 583 was initially converted to caffeic acid-vinylcatechol com- 584 pounds, some of which contributed to the enhanced inhibitory 585 activities of the products produced at $170{ }^{\circ} \mathrm{C}$ or less. 586 Subsequently, caffeic acid was converted to the moderately 587 active vinylcatechol oligomers, which were then transformed 588 into weakly active catechol-reacted compounds, the production 589 of which decreased the XO inhibitory activities of the thermal 590 reaction products produced at the temperatures above $170{ }^{\circ} \mathrm{C} .591$ Although not all of the produced constituents of the thermal 592 reaction products could be identified because of their 593 complexity, the observed structural differences in the 594 constituents might induce the enhanced XO inhibitory 595 activities of the thermal reaction products. Notably, the 596 thermal treatment at $170{ }^{\circ} \mathrm{C}$, which exhibited the maximum 597 $\mathrm{XO}$ inhibitory activity, coincides with the general roasting 598 conditions of food processing. ${ }^{26}$ Caffeic acid and its derivatives, 599 including chlorogenic acid, are widely distributed in plant- 600 derived foodstuffs. ${ }^{27}$ Therefore, the processing of foodstuffs by 601 roasting might result in significant $\mathrm{XO}$ inhibitory activity 602 through the thermal reactions of caffeic acid derivatives. In 603 terms of coffee beverages, we previously reported that only 604 roasted coffee beans exhibited XO inhibitory activity, ${ }^{16}$ which 605 enhanced the ability of coffee to prevent gout. ${ }^{28}$ Frank et al. ${ }^{13} 606$ 


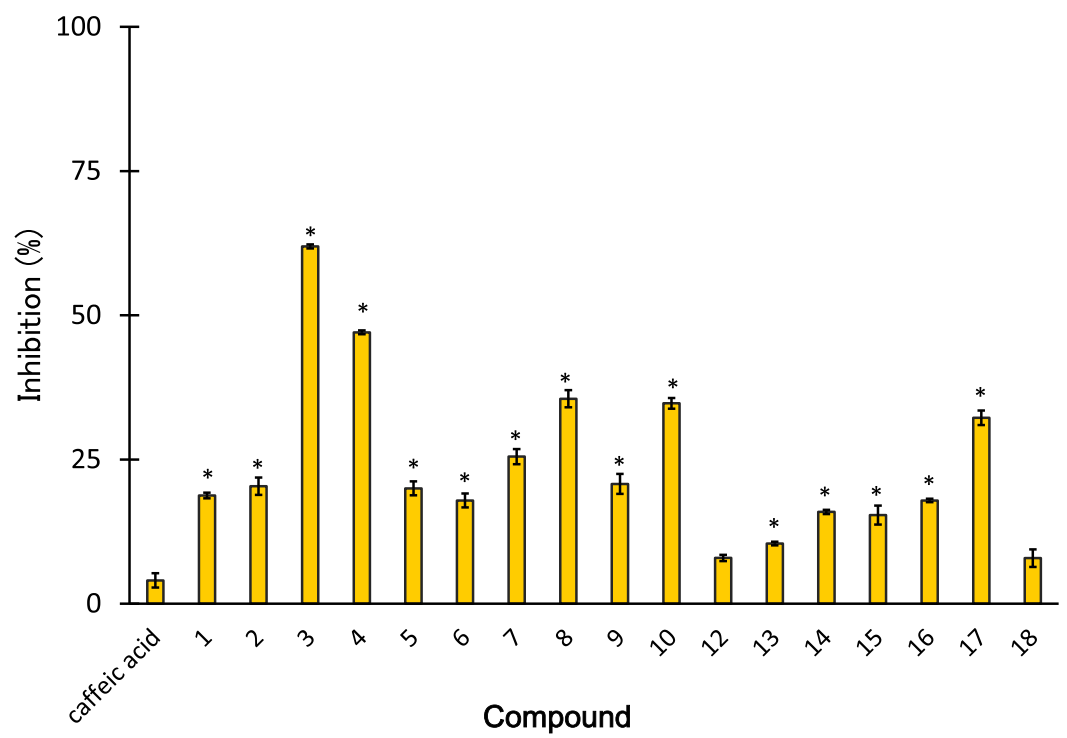

Figure 6. Xanthine oxidase inhibitory activities of identified compounds 1-18 and caffeic acid (200 $\mu \mathrm{mol} / \mathrm{L})$. Data are expressed as the means \pm SE $(n=3)$. Asterisks $(*)$ indicate significant differences $(p<0.05)$ when compared with caffeic acid (Dunnett's test). Allopurinol $(0.5 \mu$ mol/L), a positive control sample, showed $52.3 \%$ inhibition under the same conditions.

607 reported the existence of various vinylcatechol oligomers in 608 roasted coffee as bitter-tasting compounds by using LC-MS 609 techniques. Although pyrogallol and chlorogenic lactones have 610 been identified as significant $\mathrm{XO}$ inhibitors present in roasted 611 coffee beans, ${ }^{16,17}$ vinylcatechol oligomers and related com612 pounds might also play a role in the XO inhibitory activity. 613 Differences in inhibitory ability due to the different reaction 614 temperatures should also be considered when determining the 615 conditions of the roasting process of raw coffee beans. 616 Optimized roasting conditions should be useful for the 617 production of health-functional coffee beverages that exhibit 618 XO inhibitory activity.

619 Although the bioavailabilities of the identified phenylindanes 620 and vinylcatechol oligomers have not been examined to date, 621 the abilities of caffeic acid and the related phenolic acids in 622 coffee have been well studied. ${ }^{29,30}$ These compounds can be 623 absorbed in humans in their conjugated and nonconjugated 624 forms. Ota et al. ${ }^{31}$ examined the interaction of these phenolic 625 acids and corresponding vinylcatechol derivatives with lipid 626 membranes. The results revealed that the more nonpolar 627 vinylcatechols displayed stronger interactions with the 628 membrane, which were related to their bioavailability. The 629 identified thermal reaction products are also more nonpolar 630 than caffeic acid; therefore, higher bioavailability is expected 631 for the product constituents. When the nonpolar thermal 632 reaction products of caffeic acid are absorbed by humans, they 633 might exhibit characteristic functions in the human body. XO 634 is localized in the liver and intestine and produces uric $635 \mathrm{acid}^{32,33}$ the over accumulation of which is responsible for the 636 development of gout. ${ }^{28}$ The absorbed thermal products might 637 play a role in inhibiting XO from overworking when reaching 638 the liver or intestine, thereby preventing the development of 639 gout.

\section{ASSOCIATED CONTENT}

\section{${ }_{641}$ S Supporting Information}

642 The Supporting Information is available free of charge on the 643 ACS Publications website at DOI: 10.1021/acs.jafc.9b03633.
Figure S1. HPLC analytical data of various thermal 644 reaction products $\left(110-290{ }^{\circ} \mathrm{C}\right)$ of caffeic acid and 645 reference samples (caffeic acid and polystyrene marker): 646 chromatograms obtained using (A) ODS column and 647 (B) GPC column (PDF) Table S1. NMR data of vinylcatechol oligomers 9 and 649 10 (PDF)

\section{AUTHOR INFORMATION}

*Tel. and Fax: +81-6-6605-2813. E-mail: masuda_t@life. 653 osaka-cu.ac.jp.

\section{ORCID}

Toshiya Masuda: 0000-0001-6691-9464 $15 \mathrm{H} 02892$ for T.M.) and a collaborative research fund 659 between Ajinomoto-AGF (Tokyo, Japan) and Osaka City 660 University.

Notes

The authors declare no competing financial interest.

\section{REFERENCES}

(1) Yahya, H.; Linforth, R. S. T.; Cook, D. J. Flavour generation 665 during commercial barley and malt roasting operations: a time course 666 study. Food Chem. 2014, 145, 378-378.

(2) Barham, P. The science of cooking; Springer-Verlag GmbH: 668 Heidelberg, 2001.

(3) van Boekel, M.; Fogliano, V.; Pellegrini, N.; Stanton, C.; Scholz, 670 G.; Lalljie, S.; Somoza, V.; Knorr, D.; Jasti, P. R.; Eisenbrand, G. A 671 review on the beneficial aspects of food processing. Mol. Nutr. Food 672 Res. 2010, 54, 1215-1247.

(4) Sondheimer, E. On the distribution of caffeic acid and the 674 chlorogenic acid isomers in plants. Arch. Biochem. Biophys. 1958, 74, 675 $131-138$.

(5) Upadhyay, R.; Mohan Rao, L. J. An outlook on chlorogenic 677 acids-Occurrence, chemistry, technology, and biological activities. 678 Crit. Rev. Food Sci. Nutr. 2013, 53, 968-984.

(6) Farah, A.; Donangelo, C. M. Phenolic compounds in coffee. 680 Braz. J. Plant Physiol. 2006, 18, 23-26. 
682 (7) Oestreich-Janzen, S. Chemistry of coffee. Reference Module in 683 Chemistry, Molecular Sciences and Chemical Engineering 2013, 1-28.

684 (8) Moon, J.-K.; Shibamoto, T. Formation of volatile chemicals from 685 thermal degradation of less volatile coffee components: qunic acid, 686 caffeic acid, and chlorogenic acid. J. Agric. Food Chem. 2010, 58, $6875465-5470$.

688 (9) Ludwig, I. A.; Clifford, M. N.; Lean, M. E. J.; Ashihara, H.; 689 Crozier, A. Coffee: biochemistry and potential impact on health. Food 690 Funct. 2014, 5, 1695-1717.

691 (10) Grosch, W. Flavor of coffee. A review. Nahrung 1998, 42, 344692350.

693 (11) Moreira, A. S. P.; Nunes, F. M.; Domingues, M. R.; Coimbra, 694 M. A. Coffee melanoidins: structures, mechanisms of formation and 695 potential health impacts. Food Funct. 2012, 3, 903-915.

696 (12) Frank, O.; Zehentbauer, G.; Hofmann, T. Bioresponse-guided 697 decomposition of roast coffee beverage and identification of key taste 698 compounds. Eur. Food Res. Technol. 2006, 222, 492-508.

699 (13) Frank, O.; Blumberg, S.; Kunert, C.; Zehentbauer, G.; 700 Hofmann, T. Structure determination and sensory analysis of bitter701 tasting 4-vinylcatechol oligomers and their identification in roasted 702 coffee by means of LC-MS/MS. J. Agric. Food Chem. 2007, 55, 19457031954.

704 (14) Choi, H. K.; Curhan, G. Coffee, tea, and caffeine consumption 705 and serum uric acid level: The third national health and nutrition 706 examination survey. Arthritis Rheum. 2007, 57, 816-821.

707 (15) Park, K. Y.; Kim, H. J.; Ahn, H. S.; Kim, S. H.; Park, E. J.; Yim, 708 S.-Y.; Jun, J.-B. Effects of coffee consumption on serum uric acid: 709 systematic review and meta-analysis. Semin. Arthritis Rheum. 2016, 45, $710580-586$.

711 (16) Honda, S.; Miura, Y.; Masuda, A.; Masuda, T. Identification of 712 crypto- and neo-chlorogenic lactones as potent xanthine inhibitors in 713 roasted coffee beans. Biosci., Biotechnol., Biochem. 2014, 78, 21107142116.

715 (17) Honda, S.; Masuda, T. Identification of pyrogallol in the ethyl716 acetate-soluble part of coffee as the main contributor to its xanthine 717 oxidase inhibitory activity. J. Agric. Food Chem. 2016, 64, 7743-77499. 718 (18) Seegmiller, J. E.; Grayzel, A. I.; Laster, L.; Liddle, L. Uric acid 719 production in gout. J. Clin. Invest. 1961, 40, 1304-1314.

720 (19) Stadler, R. H.; Welti, D. H.; Stämpfli, A. A.; Fay, L. B. Thermal 721 decomposition of caffeic acid in model systems: identification of novel 722 tetraoxygenatedphenylindane isomers and their stability in aqueous 723 solution. J. Agric. Food Chem. 1996, 44, 898-905.

724 (20) Fukuyama, Y.; Hidaka, K.; Masuda, A.; Masuda, T. Novel 725 xanthine oxidase $(\mathrm{XO})$ inhibitory phenylindanes produced by thermal 726 reaction of caffeic acid. Biosci., Biotechnol., Biochem. 2018, 82, 18257271828

728 (21) Rahn, W.; König, W. A. GC/MS investigations of the 729 constituents in a diethyl ether extract of an acidified roast coffee 730 infusion. J. High Resolut. Chromatogr. 1978, 1, 69-71.

731 (22) Wang, Q.; Tang, W.; Feng, X.; Xu, X.; Yin, M.; Shan, Y.; Chen, 732 Y.; Wang, M.; Guan, F.; Zhao, Y.; Zhang, J. Mailuoning 733 dihydroanthracene as well as preparation method and use thereof. 734 Chinese patent, CN 103641688 (B), March 25, 2015.

735 (23) Kondrakov, A. O.; Ignatev, A. N.; Frimmel, F. H.; Bräse, S.; 736 Horn, H.; Revelsky, A. I. Formation of genotoxic quinones during 737 bisphenol A degradation by $\mathrm{TiO} 2$ photocatalysis and UV photolysis: 738 A comparative study. Appl. Catal., B 2014, 160-161, 106-114.

739 (24) Ayer, W. A.; Singer, P. P. Phenolic metabolites of the bird's nest 740 fungus. Phytochemistry 1980, 19, 2717-2721.

741 (25) Terpinc, P.; Polak, T.; Segatin, N.; Hanzlowsky, A.; Ulrih, N. 742 P.; Abramovič, H. Antioxidant properties of 4-vinyl derivatives of 743 hydroxycinnamic acids. Food Chem. 2011, 128, 62-69.

744 (26) Liebich, N. M.; Douglas, D. R., Dr; Zlatkis, A.; Müggler745 Chavan, F.; Donzel, A. Volatile components in roast beef. J. Agric. 746 Food Chem. 1972, 20, 96-99.

747 (27) Clifford, M. N. Chlorogenic acids and other cinnamates 748 nature, occurrence, dietary burden, absorption and metabolism. J. Sci. 749 Food Agric. 2000, 80, 1033-1043.
(28) Pacher, P.; Nivorozhkin, A.; Szabó, S. Therapeutic effects of 750 xanthine oxidase inhibitors: Renaissance half a century after the 751 discovery of allopurinol. Pharmacol. Rev. 2006, 58, 87-114. 752

(29) Stalmach, A.; Clifford, M. N.; Williamson, G.; Cozier, A. 753 Phytochemicals in coffee and the bioavailability of chlorogenic acid. In 754 Teas, Cocoa and Coffee: Plant Secondary, Metabolites and Health; 755 Crozier, A., Asghida, H., Barberan, F. T., Eds; Blackwell Publishing: 756 Hoboken, NJ, 2012; pp 143-165.

(30) Nardini, M.; Cirillo, E.; Natella, F.; Scaccini, C. Absorption of 758 phenolic acids in humans after coffee consumption. J. Agric. Food 759 Chem. 2002, 50, 5735-5741.

760

(31) Ota, A.; Abramovič, H.; Abram, V.; Poklar Ulrih, N. 761 Interactions of p-coumaric acid, caffeic acid and ferulic acids and 762 their styrenes with model lipid membranes. Food Chem. 2011, 125, 763 $1256-1261$.

(32) Al-Khalidi, U. A. S.; Chaglassian, T. H. The species distribution 765 of xanthine oxidase. Biochem. J. 1965, 97, 318-320.

(33) Sarnesto, A.; Linder, N.; Raivio, K. O. Organ distribution and 767 molecular forms of human xanthine dehydrogenase/xanthine oxidase 768 protein. Lab. Invest. 1996, 74, 48-56. 